\title{
Sequence Microbiostratigraphy of Jahrum and Asmari Formation in Shiraz Area, Zagros, Fars, Iran
}

\author{
Mirzaee Mahmoodabadi Reza \\ Department of Geology, Estahban Branch, Islamic Azad University, Estahban, Iran \\ Email: $r$ mirzaeem@iauest.ac.ir, rmirzaeem1@Hotmail.com
}

Received 23 February 2014; revised 20 March 2014; accepted 27 March 2014

Copyright (C) 2014 by author and Scientific Research Publishing Inc.

This work is licensed under the Creative Commons Attribution International License (CC BY). http://creativecommons.org/licenses/by/4.0/

\section{Open Access}

\section{Abstract}

The study of sequence microbiostratigraphy of Jahrum and Asmari formation in Shiraz, Fars, Zagros, SW of Iran and recognition of relationship between depositional sequence parameters and microbiostratigraphy 3 stratigraphic sections (Beyza, Sarvestan A, B and Estahban sections) have been selected and studied. Jahrum and Asmari formations in study area with unconformity overlying together have been exposed. Based on Field and laboratory studies such as microfossils, microbiostratigraphy, microfaceis, sedimentary environment models and sequence stratigraphy evidences recognized 3 depositional sequences in study area that presented during Paleocene-Oligomiocene. Jahrum formation consists of one depositional sequence and Asmari formation consists of two depositional sequences. Microfossils and microbiostratigraphy studies will lead to the identification of 6 biozones in the studied area. In Beyza and Estahban sections biozones 1, 2 and 3 are related to Jahrum formation and suggest Paleocene to Middle Eocene age for this formation and biozone 4 is related to Asmari formation and suggests Oligocene age for this formation. In Sarvestan section biozones 1, 2 and 3 are related to Jahrum formation and suggest Paleocene to Middle Eocene age for this formation and biozones 4 and 5 are related to Asmari formation and these biozones indicate Oligocene-Miocene (Aquitanian) age for Asmari formation. Sequence microbiostratigraphy studies indicate that biozones of Jahrum formation are formed in DS1 and biozones of Asmari formation are formed in DS2 and DS3. Also, some relationship between depositional sequence parameters and distribution of microfossils and biozones as in the case of in SB1 and LST facies didn't found any microfossil and we can't suggest biozonation. In study area upper part of HST of DS1 (Jahrum formation) and some biozones related to Upper Eocene have been eliminated, for example in Estahban, Sarvestan B and Beyza sections all biozones related to Upper Paleocene to Middle Eocene and eliminated biozones of Upper Eocene. In study area SB2 existed in lower boundary of DS1 (between Sachun and Jahrum formation) and between DS2 and DS3 of Asmari formation. Some parts of biozones in study area could correlate with SB2. For example for upper limit of biozones no 4 in Estahban section overlies to SB2 of DS2 in Asmari formation. Pa- 
leoecological situation in TST systems tract suitable for reproduction and growth large foraminifera and biozones 1, 2 and 3 are formed in systems tract. MFS and MFZ in all sections are recognized by mixed pelagic and benthonic foraminifera wackestone. More biozones in Jahrum and Asmari formations have been identified in HST system tract. For example in Beyza section biozones 2 and 3 (Jahrum formation) and biozone 4 (Asmari formation) are in HST. In Saevestan B section biozones 3 and 4 (Jahrum formation) and biozones 5 and 6 (Asmari formation) are in this system tract. In Estahban section biozones 3 and 4 (Jahrum formation) and biozones 4 and 5 (Asmari formation) have been in HST. Also, tests of most identified large foraminifera in HST such as $\mathrm{Al}$ veolona sp, Alveolina aragonensis, Austrotrilina sp, Austrotrilina asmaricus and Archias sp are made of porcelaneous calcite and foraminiferal tests in TST systems tract, such as Nummulites sp. Nummulites intermedius, Nummulites fichtelli and Operculina sp are made of hyaline calcite.

\section{Keywords}

Sequence Stratigraphy, Microbiostratigraphy, Jahrum Formation, Asmari Formation, Shiraz, Zagros, Iran

\section{Introduction}

Paleocene-Oligomiocene sediments in study area cover two formations: Jahrum and Asmari. Jahrum formation consists of limestone, dolomitic limestone and dolomite. Lower contact of Jahrum with Sachun formation is transitional and upper contact with Asmari formation is erosional. The lower boundary of the Asmari Formation is exposed and underlain by the Jahrum Formation and the upper boundary is exposed and overlain by the Razak Formation and erosional. This formation is well-known as a major hydrocarbon reservoir in Zagros Basin, southwestern Iran and dominantly formed of limestone and dolomitic limestone [1]. In this research, relationship between sequence stratigraphy, relative sea level change, system tract microfossils content and microbiostratigraphy has been studied.

\section{Materials and Methods}

This paper is the first report on the relative sequence stratigraphy evidences and microbiostratigraphy of the Jahrum and Asmari Formations at the Shiraz area, Fars, SW of Iran. For study of sequence microbiostratigraphy of Jahrum and Asmari formation 3 stratigraphic sections selected and studied. More than 650 thin sections were analyzed for description of lithofacies and biofacies characterizes. The most samples contain well preserved and abundant larger benthonic foraminifera such as Nummulitidae, Alveolinidae, Soritidae, Peneropelidae and Miliolidae families. Theses faunas are good tools for biofacies analysis, recognition of the relationship between sequence stratigraphy evidences and microbiostratigraphy. Biostratigraphic data of the Jahrum formation was established by Wynd in 1967 [2]. Table 1 shows biozonation of Jahrum formation. Adams and Bourgeois in 1967 [3] designed four assemblage zones for the Asmari Formation, Table 2 shows this biozonations. In 2009 Laursen et al. [4]. Published a new biozonation of the Upper Oligocene-Lower Miocene sediments by distribution of larger benthonic foraminifera for Asmari formation that Table 3 shows this biozonations.

\section{Geologic and Stratigraphic Setting}

The study area is located SW of the Zagros Mountains, which is a Paleocene-Oligomiocene sediments in foldthrust belt Zagros that located in Fars area. The Zagros is the result of a multi-phased collision between the Arabian plate, the Neo-Tethys Ocean, and the central Iran micro plate [5]. As such, both 3 studied sections include two formations; Jahrum and Asmari, Figure 1 shows the geological setting and Geographical location of the studied sections. Figure 1 shows the geological setting and Geographical location of the studied sections.

\section{Lithostratigraphy of the Studied Sections}

The geographic coordinates of the base of the selected sections, together with their lithostratigraphical character- 
Table 1. Biozonation of the Jahrum formation, Wynd, 1965.

\begin{tabular}{ccc}
\hline Age & Zone No. & Biozones \\
\hline Upper Eocene & 53 & Chapmanina-Pellatispira-Baculogypsinoides Assemblge zone \\
Middle Eocene & 51 & Nummulites-Alveolina Assemblage subzone \\
Middle Eocene & 50 & Dictyoconus-Coskinolina-Orbitolites camplanatous Assemblage subzone \\
Middle Eocene & 49 & Linderina Acro subzone \\
Middle Eocene & 48 & Somalina Acro subzone \\
Lower Eocene & 44 & Operorbitolites sub-Acro zone \\
Paleocene & 43 & Miscellanea-Katina Assemblage zone \\
\hline
\end{tabular}

Table 2. Biozonation of the Asmari formation, Adams and Bourgoies, 1967.

\begin{tabular}{ccc}
\hline Age & Rock unit & biozones \\
\hline Burdigalian & Upper Asmari & Borealis melo, Meandropsina iranica \\
Aquitanian & Middle Asmari & Miogypsinoides, Archias, Valvulinid \\
Oligocene & Lower Asmari & Eulepidina, Nephrolepidina, Nummulites \\
\hline
\end{tabular}

Table 3. Biozonation of the Asmari formation, Laursen et al. 2009.

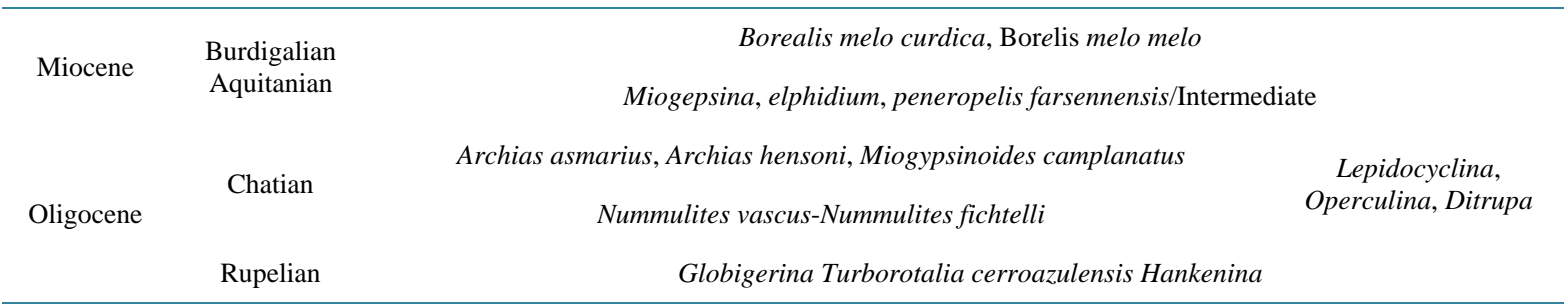

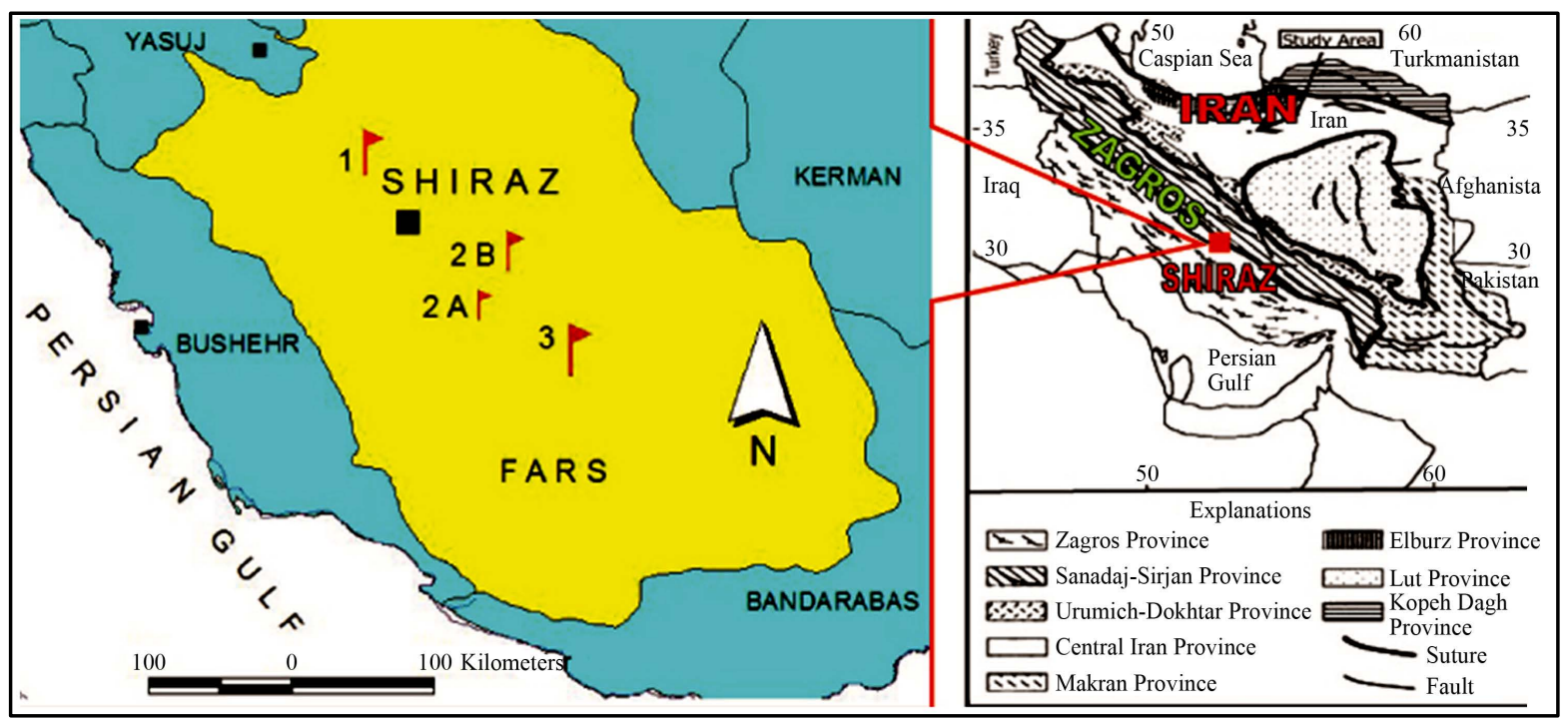

Figure 1. A: Geographical situation of the studied sections in study area: 1-Beyza section; 2A-Savestan A section (Koh-e Meyan Jangl), 2 B Sarvestan B section (Koh-e Ahmadi) 3-Estahban Section.

ristics are summarized in Table 4. Figure 2 shows lithostratigraphical relationship between formation in Fars area, SW of Iran and Figure 3 shows some field photos of study area. 
Table 4. The geographic coordinates and lithostratigraphy of he studied sections.

\begin{tabular}{|c|c|c|c|c|c|c|c|c|}
\hline No & Section Name & Formation & Dominant Lithology & $\begin{array}{l}\text { Coordinate } \\
\text { U.T.M }\end{array}$ & $\begin{array}{c}\text { Lower } \\
\text { Limit }\end{array}$ & $\begin{array}{c}\text { Thick } \\
\text { (Jahrum) }\end{array}$ & $\begin{array}{l}\text { Thick } \\
\text { (Asmari) }\end{array}$ & $\begin{array}{l}\text { Upper } \\
\text { Limit }\end{array}$ \\
\hline 1 & Beyza & $\begin{array}{l}\text { Sachun, Jahrum, } \\
\text { Asmari, Razak }\end{array}$ & $\begin{array}{l}\text { Ferroginous Limestone, } \\
\text { Dolomit, Dolomitic } \\
\text { Limestone }\end{array}$ & $\begin{array}{l}52^{\circ} 20^{\prime} 45^{\prime \prime} \mathrm{E} \\
29^{\circ} 50^{\prime} 50^{\prime \prime} \mathrm{N}\end{array}$ & Sachun & $350 \mathrm{~m}$ & $45 \mathrm{~m}$ & Razak \\
\hline $2 \mathrm{~A}$ & $\begin{array}{c}\text { Sarvestan A } \\
\text { (Koh-e Meyan Jangal) }\end{array}$ & $\begin{array}{c}\text { Tarbur, Sachun, } \\
\text { Jahrum, Asmari, Razak }\end{array}$ & $\begin{array}{l}\text { Dolomit, Dolomitic } \\
\text { Limestone, Dolomite }\end{array}$ & $\begin{array}{l}53^{\circ} 20^{\prime} 15^{\prime \prime} \mathrm{E} \\
29^{\circ} 11^{\prime} 15^{\prime \prime} \mathrm{N}\end{array}$ & Sachun & $170 \mathrm{~m}$ & Eroded & Razak \\
\hline $2 \mathrm{~B}$ & $\begin{array}{c}\text { Sarvestan B } \\
\text { (Koh-e Ahmadi) }\end{array}$ & $\begin{array}{c}\text { Tarbur, Sachun, } \\
\text { Jahrum, Asmari, Razak }\end{array}$ & $\begin{array}{l}\text { Limestone, Dolomitic } \\
\text { Limestone, Dolomite }\end{array}$ & $\begin{array}{l}53^{\circ} 12^{\prime} 15^{\prime \prime} \mathrm{E} \\
29^{\circ} 20^{\prime} 26^{\prime \prime} \mathrm{N}\end{array}$ & Sachun & $250 \mathrm{~m}$ & $60 \mathrm{~m}$ & Razak \\
\hline 3 & Estahban & $\begin{array}{l}\text { Tarbur, Sachun, } \\
\text { Jahrum, Asmari, Razak }\end{array}$ & $\begin{array}{l}\text { Limestone, Dolomit, } \\
\text { Dolomitic Limestone }\end{array}$ & $\begin{array}{l}53^{\circ} 55^{\prime} 36^{\prime \prime} \mathrm{E} \\
29^{\circ} 7^{\prime} 50^{\prime \prime} \mathrm{N}\end{array}$ & Sachun & $180 \mathrm{~m}$ & $66 \mathrm{~m}$ & Razak \\
\hline
\end{tabular}

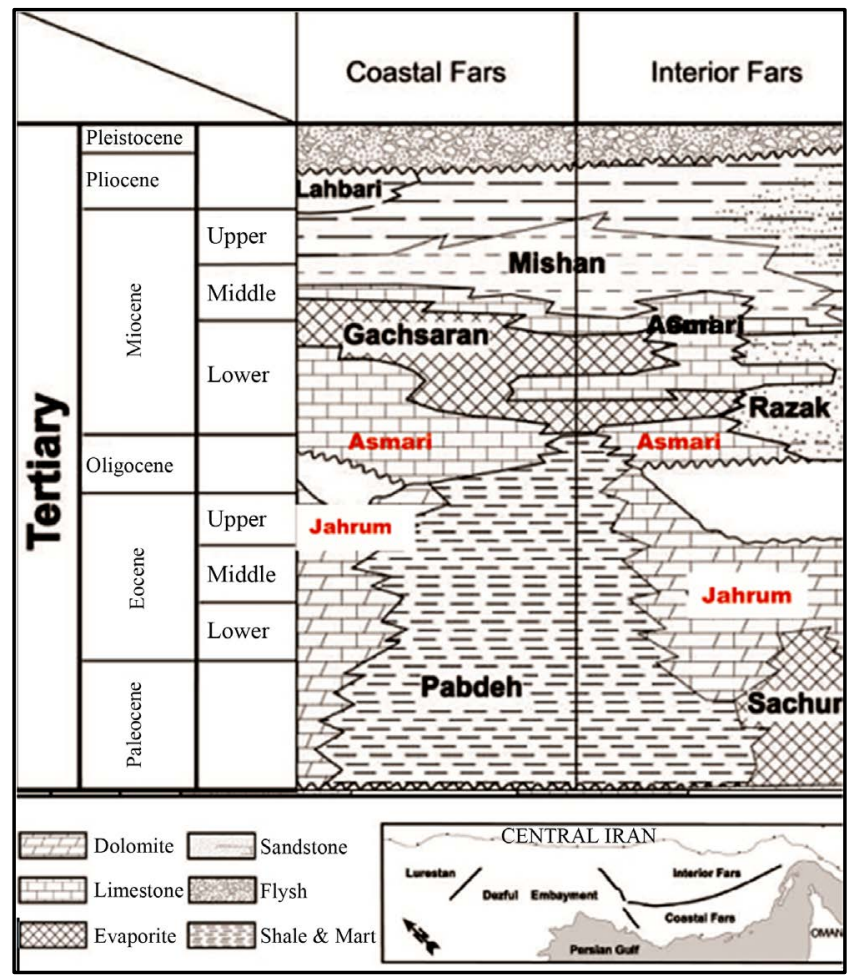

Figure 2. Lithostratigraphical relationship between formations in Fars area, SW of Iran (Modified of James \& Wynd, 1975).

\section{Sequence Microbiostratigraphy of Jahrum and Asmari Formation in Study Area}

Sequence stratigraphy is the modern knowledge of dividing sediments of a basin to sequences which are between equivalent discontinuities and continuities. Depositional sequence (DS) is the main unit of sequence stratigraphy, the upper and lower limit of which have appeared during one of the main cycles of the rise and fall of the relative sea level. Chronologically, the sequence is equivalent to the third-order sedimentary cycle comprising a large number of small-scale shallowing upward cycles or parasequences.

In general, the discontinuity surface divides younger layers from older ones, which is made up of two types: type 1 discontinuity: when the degree of falling of the sea level is more than the basin subsidence in the continental margin, and type 2 discontinuity: when the rate of falling of the sea level is slow, falling down to the middle part of the continental shelf. Each sedimentary sequence could be divided into the three systems tract, each associated with a specific part of the curve of sea level changes. The lower part of each sequence includes lows- 


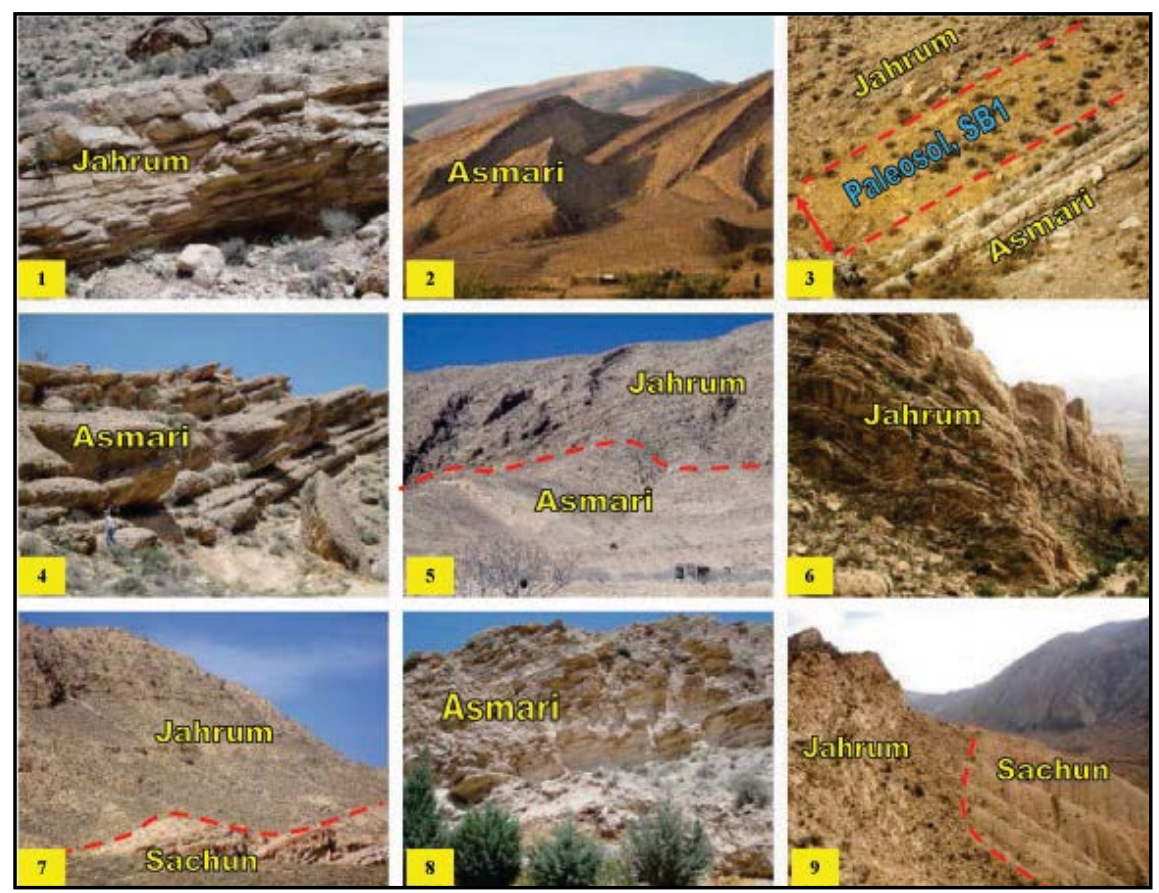

1-Dolomit and Dolomitic limestone, Jahrum formation, Sarvestan B section. 2-Medium to thick bedded dolomitic limestone, Asmari formation, Sarvestan B section. 3-Paleosol, SB1, between Jahrum and Asmari formations, Beyza section. 4-Medium to massive dolomite, Asmari formation, Sarvestan B section. 5 and 6Jahrum and Asmari formations, Estahban section. 7-Lower contact of Jahrum formation with Sachun evaporites formation, Sarvestan B section. 8-Asmari formation, Sarvestan B section. 9-Lower contact of Jahrum formation with Sachun evaporites formation, Sarvestan A section.

Figure 3. Some field photos of study area.

tand systems tract (LST), mainly consisting of epicontinental facies. The middle part of each sequence includes transgressive systems tract (TST) formed during seawater transgression, and the upper part of each sequence has also been formed with a systems tract related to the relative static state of seawater or the beginning of the seawater falling stage (Highstand systems tract) (HST).

To study of sequence microbiostratigraphy of Jahrum and Asmari formations in study area the following steps are done. 1) Detailed study of microfacies (lithofacies and biofacies) and Dunham classification, 1962 [6]. A wide range of carbonate, clastic (Litofacies) and evaporite facies have been identified in petrographic and field studies of the studied formations. Type of skeletal and non-skeletal grains, grain size and their frequency percentage, Matrix and cement have been used to discriminate and identify carbonate facies from factors such as constituents of carbonate rocks including orthochem and allochem. Skeletal grains are mostly Nummulitidae, Alveolinidae, Soritidae, Peneropelidae and Miliolidae and Algae families. For determination of carbonate microfacies use of Flugel 2004 [7]. Non-skeletal grains include pellet and intraclast, the frequency of which in some samples reaches to $50 \%$. In general, having precisely carried out the study and nomenclature of microfacies, the depositional model of each of the formations under study has been brought out according to the relative changes curve of the sea level based on their time. 2) Recognize of sedimentary environments and sub sedimentary environments based on relative sea level change. 3) Identification of sequence boundary, systems tract and depositional sequences. 4) Identification of index large foraminifera based on types and structures of test (Hyaline, porcelaneous, Agglutinated and Microgranular), chemberlets, aperture, suture, orientation and other properties. 5) Identification of biozones of Jahrum and Asmari formations in study and compare thems with previously works such as Wynd 1965, Adams and Bourgoies 1967 and Laursen et al. 2009. 4) Comparison of depositional sequences (LST, TST, HST) with recognized biozones.

For study of sequence microbiostratigraphy of Jahrum and Asmari formations in study area as references including Vail et al. (1977) [8], Loeblish \& Tappan (1988) [9], Van Wagoner et al. (1988) [10], Nadjafi et al. (2004) [11], Emery and Myers (2005) [12], Schlager et al. (2005) [13], Zhang, X. et al. (2006) [14], Bodagher and Fedale (2008) [15], Adabi et al. (2008) [16], Van Buchem et al. (2010) [17], Amirshahkarami et al. (2007 
and 2010) [18] [19], Mirzaee Mahmoodabadi et al. (2013) [20] [21], and Mirzaee Mahmoodabadi (2014) [22], have been used.

\subsection{Sequence Microbiostratigraphy of Jahrum and Asmari Formation in Beyza Section}

\subsubsection{Sequence Stratigraphy}

The Beyza section with a thickness of 395 meter comprises the Sachun, Jahrum and Asmari formations, and with regard to sequence stratigraphy, includes two third-order depositional sequences. As for the small outcrop of Sachun formation in this section, only the sequence stratigraphy of the Jahrum and Asmari formations are investigated. Jahrum formation in the studied section consisted of a third-order depositional sequence (DS1). Its lower lithostratigraphic boundary is gradational and consistent with Sachun formation and its discontinuity is 2 type (SB2). The TST systems tract of this sequence, having a thickness of 100 meter, is comprised of dolomite, dolomitic limestone and thin-bedded limestone. HST facies with a thickness of 250 meter is composed of limestone and medium to thick-bedded dolomitic limestone. Maximum flooding surface (MFS) is identified with pelagic bioclast wackestone. This systems tract is ended to the first type discontinuity (SB1) under depositional sequence of the Asmari formation. This boundary is distinctive on the land due to having paleosol and red beds. On this boundary the transgression of thin to medium-bedded carbonates of Asmari formations (TST facies) is started, and ends with HST facies of weathered medium to thick bedded limestone under Razak formation.

\subsubsection{Biozones Description}

Biozone 1: Katina sp, Lokhartia diversa, Assemblage zone.

Assemblages biozone 1 characterized by an association of Katina sp, Rotalia sp, Lokhartia diversa, Dictyoconus sp, Fallotella sp, Miliolids and Algae. This microfauna corresponds to the biozone no 43 Wynd 1965 and suggests a Upper Paleocene age for the Lower part of the Jahrum Formation.

Biozone 2: Somalina sp, Orbitolites complanatus, Assemblage zone.

This assemblage is determined by the presence of Somalina sp, Somalina Stefani, Orbitolites sp, Orbitolites complanatous, Miliolids, Dictyoconus sp and other microfossils. The faunal assemblage of this biozone corresponds to the zones no 44 and 45 Wynd 1965 and represents a Lower to Middle Eocene age for Middle part of Jahrum formation.

Biozone 3: Nummulites sp, Alveololina sp, Assemblage subzone.

This assemblage is determined by the presence of Nummulites $s p$, Alveolina sp, Orbitolites sp, Orbitolites complanatous, Miliolids, Dictyoconus sp and other microfossils. The faunal assemblage of this zone corresponds to the biozone No 51 Wynd 1965 and represents middle Eocene age for upper part of Jahrum formation.

Biozone 4: Nummulites intermedius, Nummulites fichtelli, Assemblage zone.

This assemblage zone is recognized in the lower part of the Asmari Formation and is marked by the first appearance of Nummulites intermedius and Nummulites fichtelli, other microfossils in this zone are Operculina sp, Valvulinid $s p$ and Miliolids. These microfauna correspond to Eulepidina, Nephrolepidina, Nummulites biozone of Adams and Bourgeois1967 and Nummulites vascus-Nummulites fichtelli biozone of Laursen et al. 2009. This biozone indicate an Oligocene age for Asmari formation for this section. Figure 4 shows Sequence microbiostratigraphy of Jahrum and Asmari formation in Beyza section.

\subsection{Sequence Microbiostratigraphy of Jahrum and Asmari Formation in Sarvestan A Section}

\subsubsection{Sequence Stratigraphy}

The Sarvestan A section with a thickness of 170 meter consists of only Jahrum formation. Jahrum formation in this section consisted of one third-order depositional sequence (DS1). Lower lithostratigraphic boundary is gradational and consistent with Sachun formation and its discontinuity is 2 type (SB2). The TST and HST systems tract of this sequence, are comprised of dolomite and dolomitic limestones. This systems tract is ended to the first type discontinuity (SB1) under Razak formation. Asmari formation in this section has been eroded.

\subsubsection{Biozones Description}

Biozone: Barren zone.

Because for digenesis process such as dolomitization of carbonate Jahrum formation in this section about of 


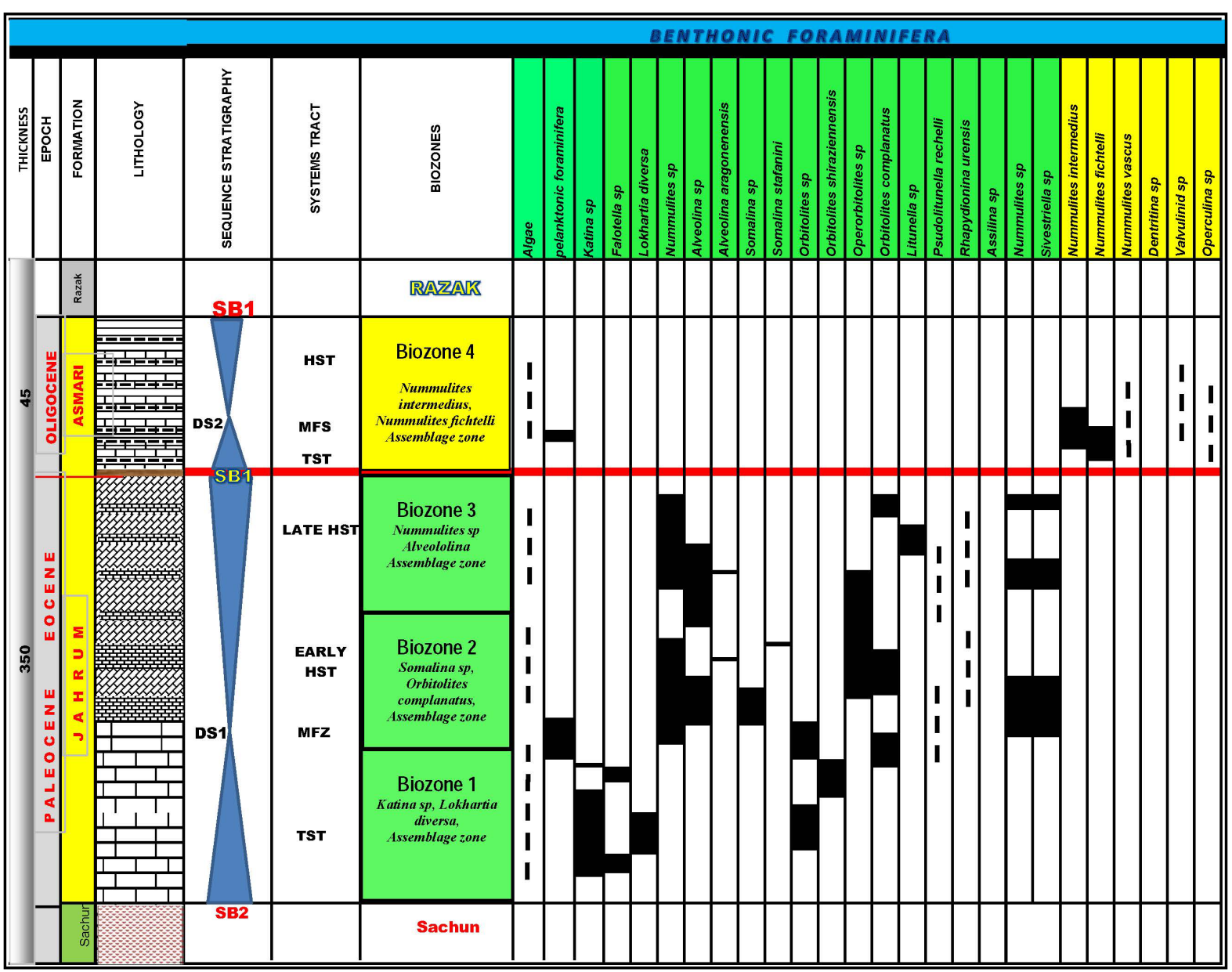

Figure 4. Sequence microbiostratigraphy of Jahrum and Asmari formations in Beyza section.

170 meter of dolomite and dolomitic limestone only a vague appearance of fossil remains and determination of microfossils is difficult .The fauna in this section only consists of miliolids and Algae. Figure 5 shows Sequence microbiostratigraphy of Jahrum and Asmari formations in Sarvestan A section.

\subsection{Sequence Microbiostratigraphy of Jahrum and Asmari Formations in Sarvestan B Section}

\subsubsection{Sequence Stratigraphy}

The Sarvestan B section, with a thickness of 310 meter includes Jahrum and Asmari formations. Sarvestan section in the region under study area is composed of 3 third-order sequences. The first sedimentary sequence is related to Jahrum Formation and sequences number 2 and 3 are related to Asmari Formation. This sequence is 250 meters thick in which TST facies are approximately 80 meters thick and are made mostly of lagoonal facies. Thickness of HST facies of the first sedimentary sequences is approximately 170 meters. These facies are made mainly of alternative lagoonal and bar facies which are characterized by increasing the thickness of layers. The lower boundary of the first sedimentary sequence is a gradual SB2 boundary with Sachun Formation and its upper boundary is an erosional SB1 evidence with Asmari Formations. The second sedimentary sequence with a thickness of 32 meters is composed of LST, TST, and HST facies in which LST facies are less than 1 meter thick and are made of red weathered sandy limes, sandstone, conglomerate and microconglomerate. TST facies of the second sequence are made of open marine facies that contain microfossils from Nummlitidae family and deposited open marine sub sedimentary environment. HST facies with 18 meters. This sequence is composed of severely weathered dolomitic limestone and dolomite. The lower boundary of the second sedimentary sequence is SB1 and its upper boundary is SB2 evidence. The third sedimentary sequence (DS3) with a thickness of 28 me- 


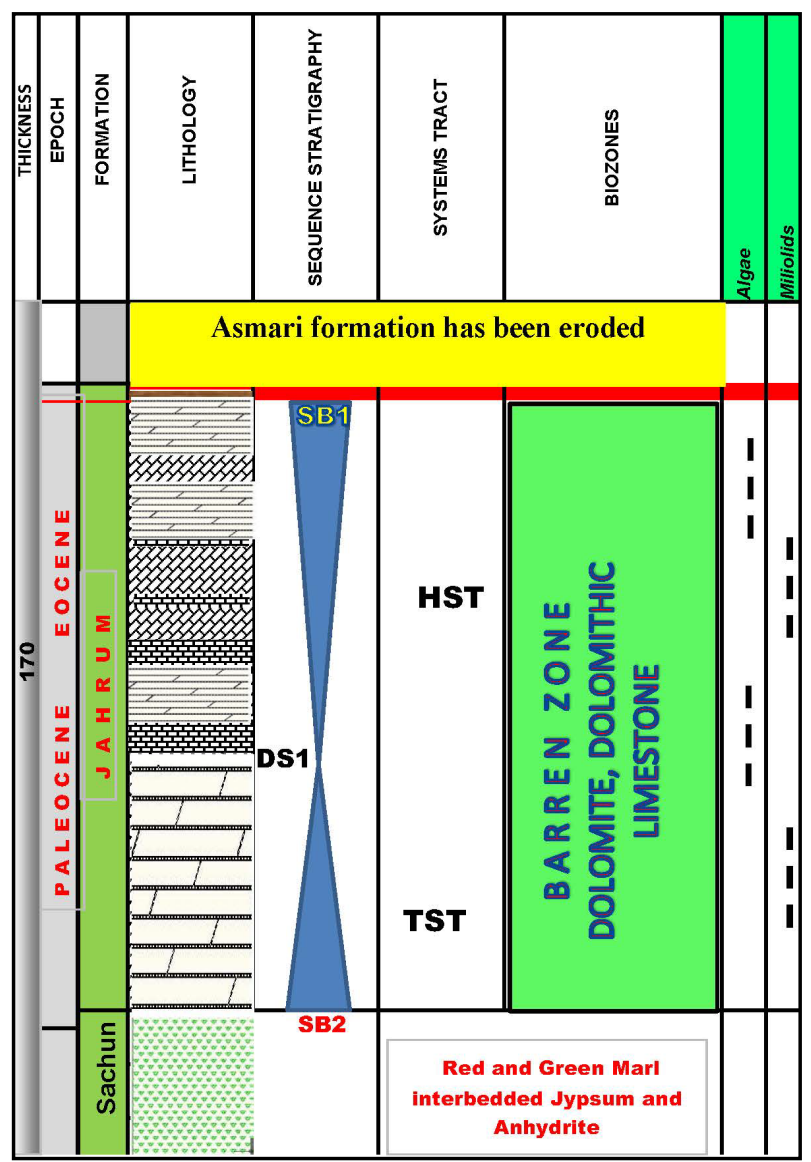

Figure 5. Sequence Microbiostratigraphy of Jahrum and Asmari formations in Sarvestan A section.

ter includes TST and HST facies. Lower boundary of this sequence is SB2 and upper boundary with Razak Formation is SB1 evidence. The upper parts of the third depositional sequence have been eroded.

\subsubsection{Biozones Description}

Biozone 1: Miscellanea, Katina, Assemblage zone.

Assemblages biozone 1 characterized by an association of Miscellanea sp, Katina sp, Rotalia sp, Nummulites $s p$, Orbitolites shirazienensis, Dictyoconus sp, Fallotella sp, Miliolids and Algae. This microfauna corresponds to the biozone no 43 Wynd 1965 and suggests a late Paleocene age for the Lower part of the Jahrum Formation.

Biozone 2: Somalina sp, Somalina Stefani Assemblage subzone.

This assemblage is determined by the presence of Somalina sp, Somalina Stefani, Orbitolites $s p$, Orbitolites omplanatous, Miliolids, Dictyoconus $s p$ and other microfossils. The faunal assemblage of this zone corresponds to the biozones No 44 and 45 Wynd 1965 and represents a Lower to Middle Eocene age for Middle part of Jahrum formation.

Biozone 3: Operorbitolites Acro zone.

This zone represents of the appearance and disappearance of Operorbitolites $s p$. Some fauna that seen in this zone, are Litunella sp, Dictyoconus sp, Nummulites sp and Miliolids. This acrozone corresponds to biozone No 44 Wynd 1965 and suggests Lower Eocene age for middle part of Jahrum formation in this section.

Biozone 4: Dictyoconus, Orbitolites camplanatous Assemblage zone.

This assemblage is determined by the presence of Dictyoconus $s p$, Orbitolites camplanatous, Orbitolites $s p$, Alveolina sp, Miliolids, and other microfossils. The faunal assemblage of this zone corresponds to the biozone No 50 Wynd 1965 and represents middle Eocene age for upper part of Jahrum formation.

Biozone 5: Miogypsinioiedes, Archias, Valvulinid Assemblage zone. 
This assemblage zone is recognized in the lower part of the Asmari Formation and is marked by the first appearance of Miogypsinioiedes, Archias sp, Valvulinid and Miliolids. These microfauna correspond to Eulepidina, Nephrolepidina, Nummulites biozones of Adams and Bourgeois1967 and Archias asmaricus, Archias hensoni, Miogypsinoides camplanatus biozone of Laursen et al. 2009. This biozone indicate an Oligocene age for Asmari formation.

Biozone 6: Austrotrilina Hochini, Austrotrilina Asmaricus, Archias, Assemblage zone.

This assemblage zone is recognized in the middle part of the Asmari Formation and is marked by the first appearance of Austrotrilina Hochini, Austrotrilina Asmaricus, Archias sp, Valvulinid and Miliolids. These microfauna correspond to Miogypsinoides, Archias, Valvulinid biozones of Adams and Bourgeois 1967 and Miogepsina, elphidium, peneropelis farsennensis biozone of Laursen et al. 2009. This biozone indicate a Miocene (Aquitanian) age for Asmari formation. Figure 6 shows Sequence microbiostratigraphy of Jahrum and Asmari formations in Sarvestan B section.

\subsection{Sequence Microbiostratigraphy of Jahrum and Asmari Formation in Estahban Section}

\subsubsection{Sequence Stratigraphy}

The Estahban section, with thickness of 180 meter includes Jahrum and Asmari formations. This section includes three third order depositional sequences. One depositional sequence DS1 is related to Jahrum Formation. DS2 and DS3 are related to Asmari Formation. The lower boundary of DS1 with Sachun formation is transitional (SB2). TST thickness of DS1 is 70 meter and made of dolomite, dolomitic limestone, and thin limestone layers. HST facies with a thickness of 110 meter is made of limestone and medium to thick layers of dolomitic limestone. Maximum flooding surface (MFS) is identified with mixed pelagic and benthonic bioclastic wackestone. This systems tract is ended to the first type discontinuity (SB1) under depositional sequence of the Asmari formation. This boundary is distinctive on the land due to having paleosol and red beds. On this boundary DS2 started by transgressive carbonates of Asmari formation. TST facies of this depositional sequence consist of thin to medium bedded limestone and HST facies consist of dolomite and dolomitic limestone. DS3 with 30 meter thickness, consist of dolomite and dolomitic limestone. TST facies of DS3 consisted of medium bedded limes-

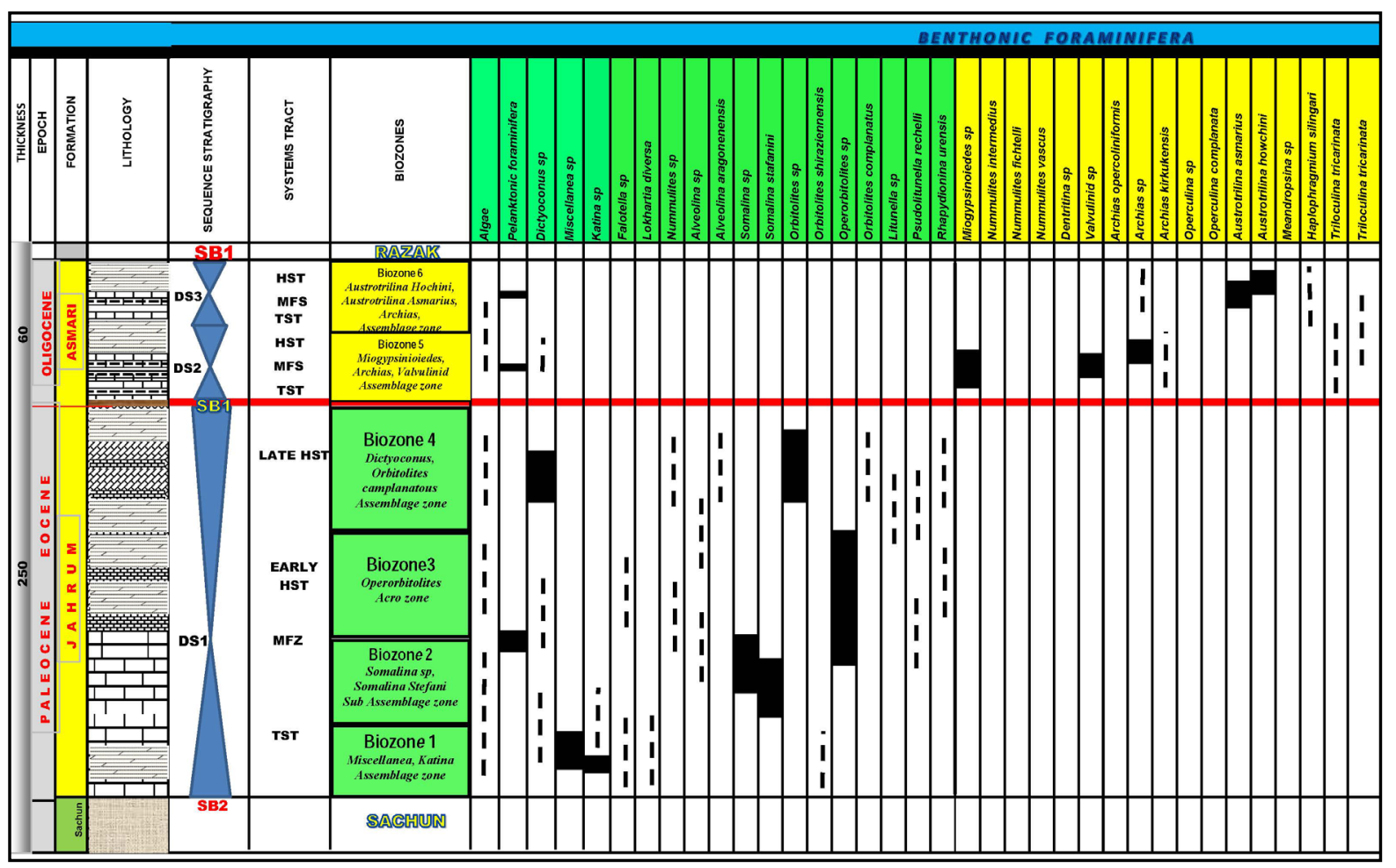

Figure 6. Sequence Microbiostratigraphy of Jahrum and Asmari formations in Sarvestan B section. 
tone and HST facies consisted of dolomite and dolomitic limestone. This depositional sequence with erosional boundary (SB1) has been under Razak clastic formation.

\subsubsection{Biozones Description}

Biozone 1: Somalina sp, Somalina Stefani Assemblage subzone.

This assemblage is determined by the presence of Somalina sp, Somalina stefani, Orbitolites sp, Orbitolites complanatous, Miliolids, Dictyoconus sp and other microfossils. The faunal assemblage of this zone corresponds to the zones no 44 and 45 Wynd 1965 and represents a lower to middle Eocene age for Middle part of Jahrum formation.

Biozone 2: Operorbitolites Acro zone.

This zone represents of the appearance and disappearance of Operorbitolites sp. Some fauna that seen in this zone, are Litunella sp, Dictyoconus sp, Nummulites sp and Miliolids. This acrozone corresponds to biozone no 44 Wynd 1965 and suggests Lower Eocene age for Middle part of Jahrum formation in this section.

Biozone 3: Dictyoconus, Coskinolina, Orbitolites complanatous Assemblage zone.

This assemblage is determined by the presence of Dictyoconus $s p$, Coskinolina sp, Orbitolites camplanatous, Orbitolites sp, Alveolina sp, Miliolids, and other microfossils. The faunal assemblage of this zone corresponds to the zone No 50 Wynd 1965 and represents Middle Eocene age for upper part of Jahrum formation.

Biozone 4: Nummulites intermedius, Nummulites fichtelli, Nummulites vascus Assemblage zone.

This assemblage zone is recognized in the lower part of the Asmari Formation and is marked by the first appearance of Nummulites intermedius, Nummulites fichtelli, Nummulites vascus. Other microfossils in this zone are such as Operculina sp, Valvulinid sp and Miliolids. These microfauna correspond to Eulepidina, Nephrolepidina, Nummulites biozones of Adams and Bourgeois1967 and Nummulites vascus-Nummulites fichtelli biozone of Laursen et al. 2009 and indicate a Oligocene age. Figure 7 shows Sequence Microbiostratigraphy of Jahrum and Asmari formation in Estahban section. Figure 8 and Figure 9 show some identified microfossils in study area.

\section{Sequence Microbiostratigraphy of Study Area}

Based on lithofacies, biofacies and sequence stratigraphy evidences recognized relationships between sequence

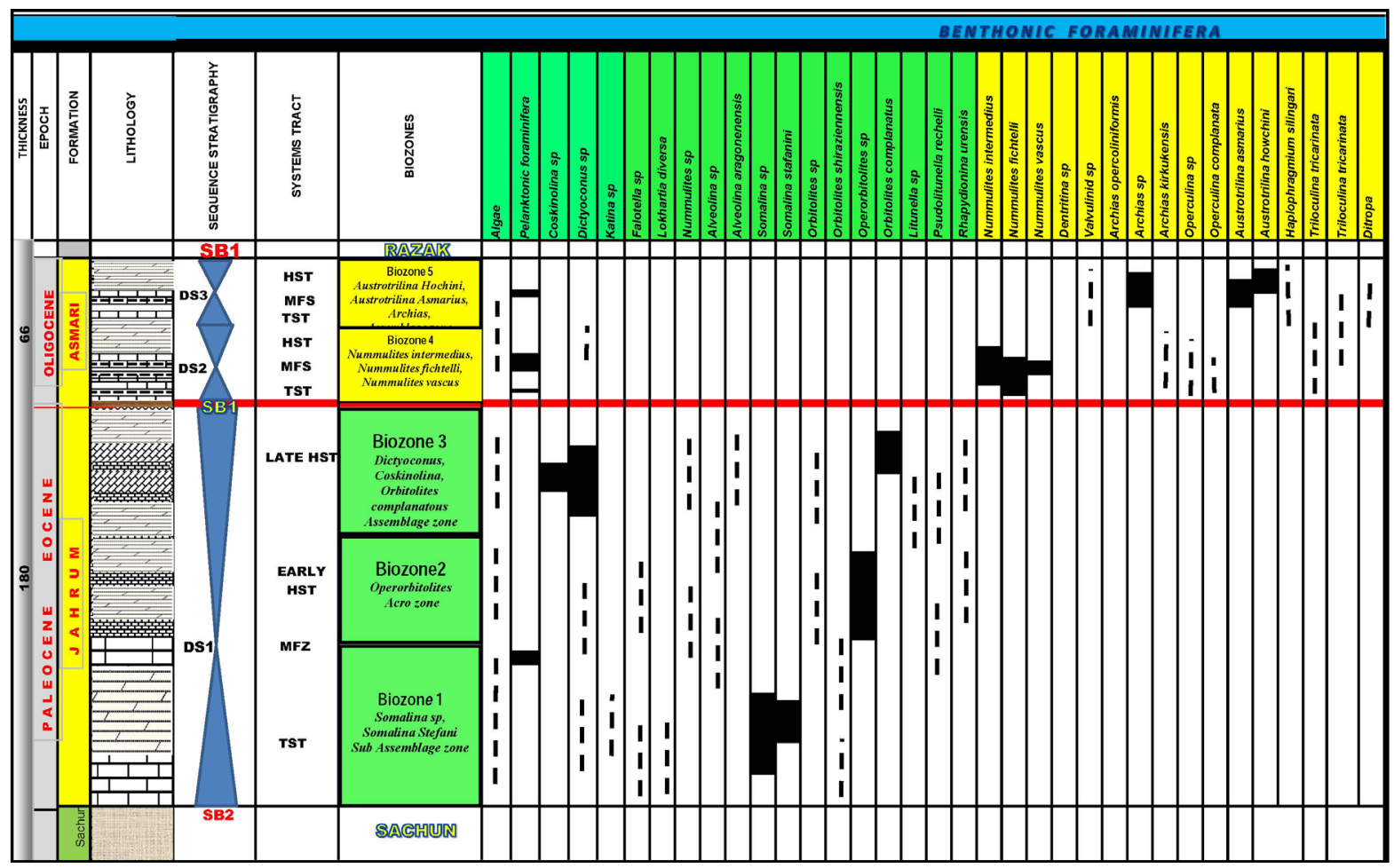

Figure 7. Sequence microbiostratigraphy of Jahrum and Asmari formations in Estahban section. 


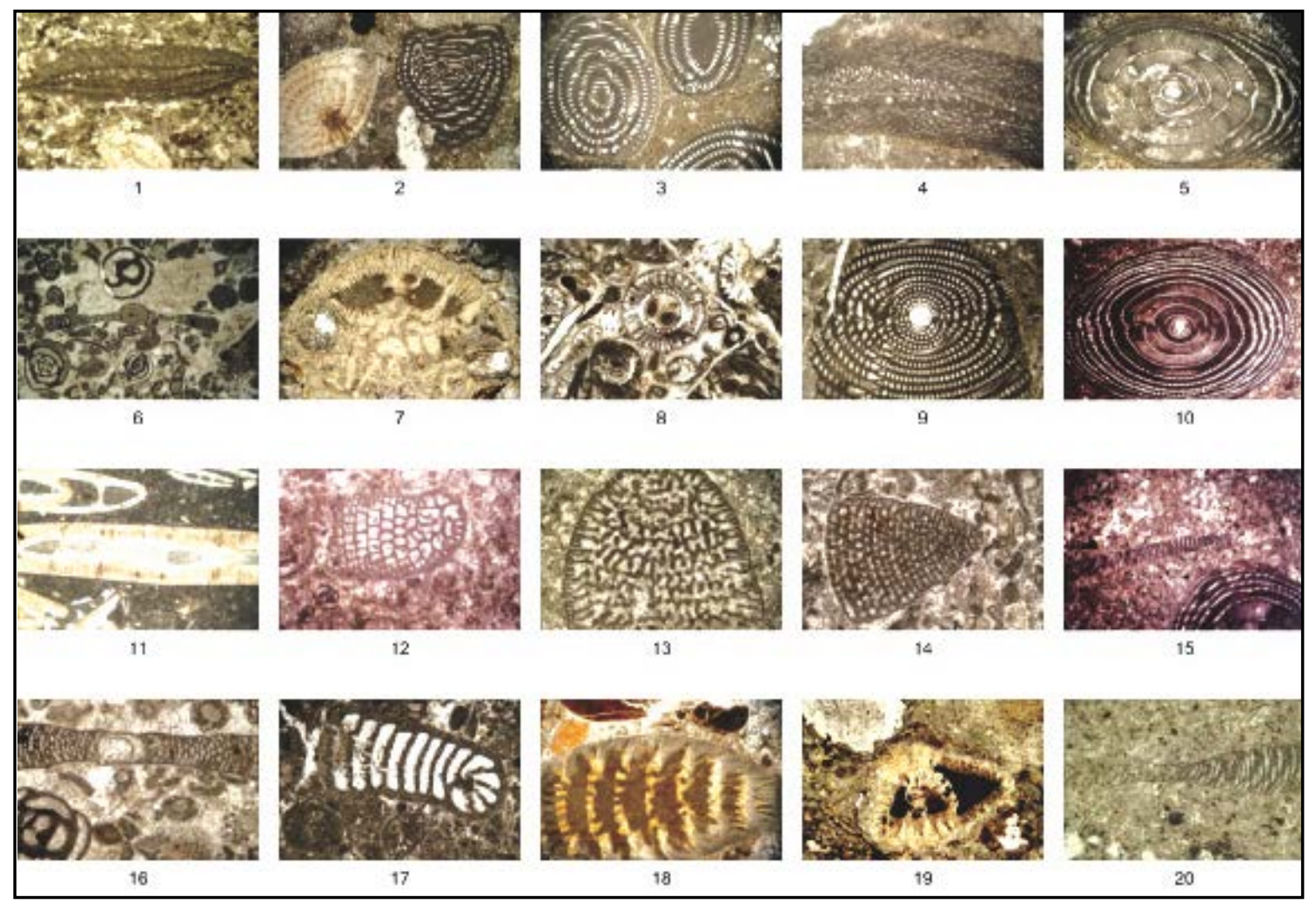

1-Somalina sp, Eocene, Axial section, $\times 10$; 2-Nummulites sp, Alveolina sp, Lower-Middle Eocene, Equiterial section, $\times 10$; 3-Alveolina sp, Lower-Middle Eocene, Equiterial section, $\times 10$; 4-Somalina Stefani, Eocene, axial section, $\times 10$; 5-Flusculina sp, Eocene, axial section, $\times 10$; 6-Orbitolites shirazienensis, Paleocene-Eocene, axial section, $\times 4$; 7-Lokhartia diversa, Paleocene-Eocene, axial section, $\times 20$; 8-Algae, Salpingoporella sp, $\times 10$; 9 and 10-Alveolina aragonensis, Eocene, Equiterial section, $\times 10$; 11-Assilina sp, Paleocene-Eocene, axial section, $\times 10$; $12-$ Koskinolina $s p$, Eocene, axial section, $\times 10$; 13-Dictyoconus sp, axial section, $\times 10 ; 14-$ Fallotella sp, Paleocene-Eocene, axial section, $\times 10$; 15-Orbitolites sp, Alveolina sp, Eocene, axial and Equiterial sections, $\times 10$; 16-Orbitolites shirazienensis, Quinqueloculina sp, PaleoceneEocene, axial section, $\times 10$; 17-Litunella rechelli, Eocene, axial section, $\times 10$; 18-Raphydionina uriensis, Eocene, axial section, $\times 10$, 19-Katina sp, Upper Paleocene-Lower Eocene, axial section, $\times 20$; 20-Operorbitolites sp, Eocene, axial section, $\times 4$.

Figure 8. Some microfossils of Jahrum formation.

strtigraphy and microbiostratigraphy in study area. Relationship between major parameters of identified depositional sequence and microbiostratigraphy in study area below is separately stated.

SB1. The effect of Pyrenean orogeny phase in upper Eocene study area have been exposed and SB1 formed between Jahrum and Asmari formations, this boundary recognized with conglomerate, micro conglomerate, lime sandstone and sandy limestone, in these facies not found fauna and flora, although it is possible existence some reworked microfossils, furthermore we can't suggest biozonation, in study area for SB1 between Jahrum, Asmari and Razak formation. Also some parts of depositional sequence and biozons eroded and eliminated, for example in all sections in study area upper part of HST of DS1 (Jahrum formation) and some biozones related to Upper Eocene have been eliminated, for example in Estahban, Sarvestan B and Beyza sections all biozones related to Upper Paleocene to Middle Eocene and eliminated biozones of Upper Eocene.

SB2. In study area SB2 exist in lower boundary of DS1 (between Sachun and Jahrum formations) and between DS2 and DS3 of Asmari formation. Some parts of biozones in study area could correlate with SB2. For example upper limit of biozones No 4 in Estahban section overlying to SB2 of DS2 in Asmari formation.

LST. This systems tract includes deposits that accumulate after the onset of relative a sea-level rise. when the sea level is at the lowest level or sea level start to transgressive lowstand systems tract are formed and often conglomerate, micro conglomerate and paleosol are formed, for example between Jahrum and Asmari formations in all studied sections in over SB1 and beginning of DS2 (Asmari formation) LST have been. LST paleoenvironment and paleoecological isn't suitable for grow and reproduce foraminifera and theses systems tract don't have any index micro fauna and flora.

TST. This systems tract is comprises of accumulated coastal onlapping deposits and MFS microfacies. Stack- 


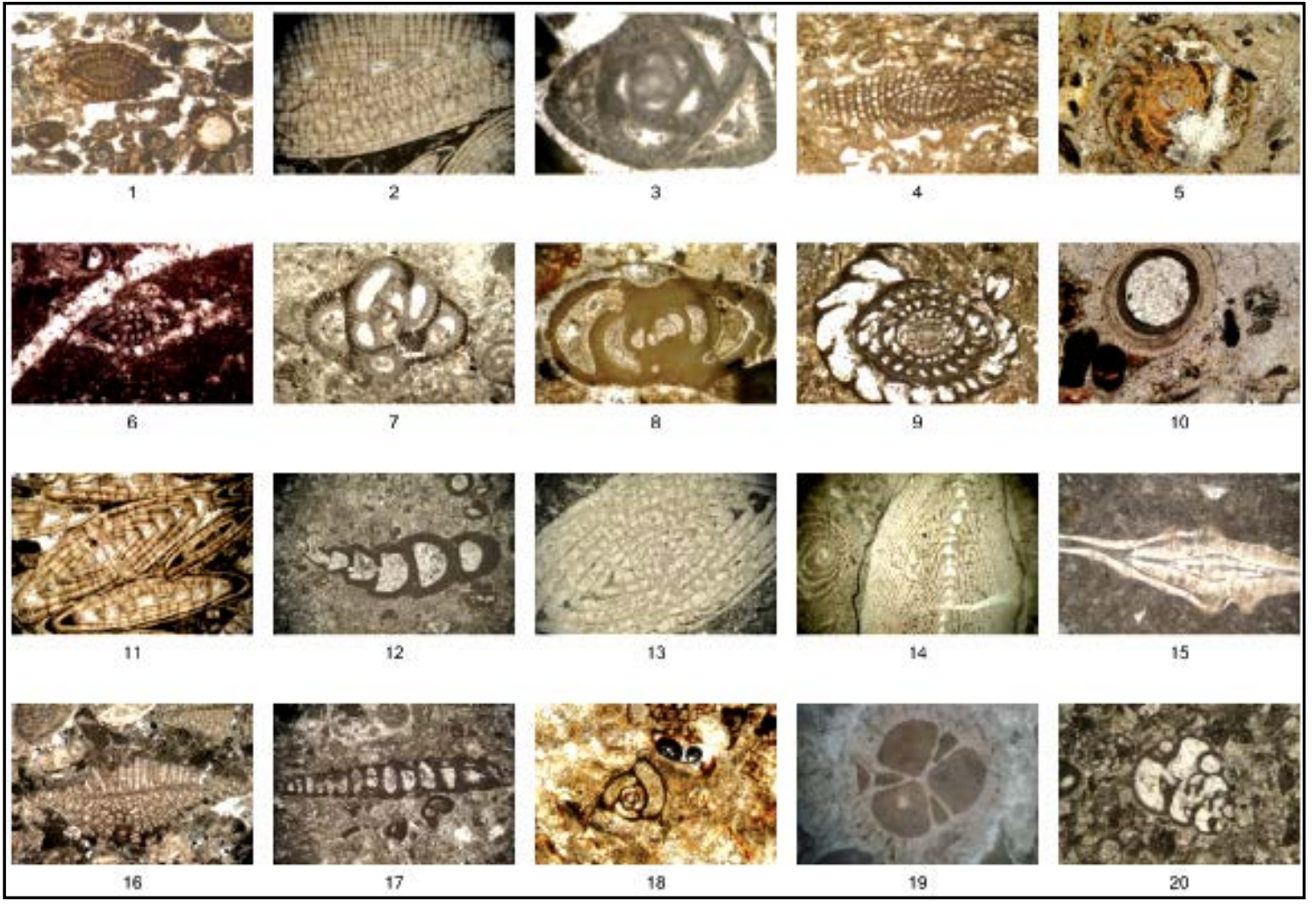

1-Archias sp, Upper Oligocene, Oblique section, $\times 10$; 2-Nummulites intermedius fichtelli, Late Oligocene, Axial section, $\times 10$; 3-Austrotrillina asmaricus, Late Oligocene, Equiterial section, $\times 10$; 4-Archias sp, Upper Oligocene, Equiterial section, $\times 10$; 5-Archias operculiniformis, Upper Oligocene, Equiterial section, $\times 10$; 6-Archias sp, Upper Oligocene, Equiterial section, $\times 10$; 7-Austrotrillina asmaricus, Late Oligocene, Equiterial section, $\times 10$; 8-Dentritina $s p$, Late Oligocene, Axial section, $\times 10$; 9-Dentritina rengi, Oligomiocene, Equiterial section, $\times 10$; 10Ditropa sp, $\times 10$, 11-Nummulites fichtelli, Late Oligocene, Axial section, $\times 10,12-$ Haplophragmium silingari, Oligocene, Axial section, $\times 10$; 13-Nummulites fichtelli, Late Oligocene, Axial section, $\times 10$; 14-Nummulites intermedius fichtelli, Late Oligocene, Axial section, $\times 2$; 15Operculina sp, Upper Eocene-Oligocene, Axial section, $\times 10$; 16-Discocyclina sp, Oligocene, Axial sextion, $\times 10$; 17-Spirolina sp, EoceneOligocene, Axial section, $\times 10$; 18-Triloculina trigonula, Oligomiocene, Equiterial section, $\times 10$; 19-Tubucellaria sp, Oligomiocene, Axial section, $\times 10$; 20-Valvulinid sp, Oligomiocene, Axial section, $\times 10$.

Figure 9. Some microfossils of Asmari formation.

ing patterns exhibit backstepping onlapping retrogradational parasequences. In cases where there is a high sediment supply the parasequences may be aggradational. In study area this systems tract include marine deposits such as thin to medium limestone and dolomitic limestone (Estahban, Sarvestan B and Beyza sections) and dolomite (Sarvestan A). Paleoecological situations (salinity, temperature, photic zone, depth, $\cdots$ ) are suitable for reproduction and growth large foraminifera. For example in Beyza and Estahban sections in biozone 1 (Jahrum formation) and biozone 2 (Asmari formation test of large foraminifera often formed hyaline microcrystalline calcite. In deposits of this systems tract in all studied sections large foraminifera related to open marine and lagoon sub sedimentary environments, for example Nummulites sp. Nummulites intermedius, Nummulites fichtelli, Operculina sp and other microfossils, especially in biozones of Asmari formation.

MFS. This surface marks by the time of maximum flooding or transgression of the shelf and it separates the transgressive and highstand systems tract. Seismically, it is often expressed as a downlap surface. Marine shelf and basinal sediments associated with this surface are the result of slow rates of deposition by pelagic-hemipelagic sediments and they are usually thin and fine grained. These fine sediments make up the condensed section. In study area accurate identification mfs is difficult and in much depositional sequence instead MFS considered maximum flooding zone (MFZ). MFS and MFZ in all section recognized by mixed pelagic and benthonic foraminifera wackestone in Jahrum and Asmari formations. There are commonly widespread thin bedded concentrations of fauna (condensed sections) with high abundant and diversity.

HST. This systems tract formed during the late stage of base level rise the rate of sea level rise drops below the sedimentation rate. In this period of sea level Highstand System Tract is formed. It is bounded by maximum 
flooding surface at the base and sequence boundary type one (SB1), type two (SB2) and correlative conformity (C.C) on the top. paleoecological parameters are suitable for growth and expanding large foraminifera in HST. In study area HST have been formed of thick to massive limestone, dolomithic limestone and limestone and commonly weathered.

In study area more identified biozones existent in HST. For example in Beyza section biozones 2 and 3 (Jahrum formation) and biozone 4 (Asmari formation) are in HST. In Saevestan B section biozones 3 and 4 (Jahrum formation) and biozones 5 and 6 (Asmari formation) are in this systems tract. In Estahban section biozones 3 and 4 (Jahrum formation) and biozones 4 and 5 (Asmari formation have been in HST.

More tests of large benthonic foraminifera in HST systems tract are porcelaneous calcite, such as Alveolona sp, Alveolina aragonensis, Austrotrilina sp, Austrotrilina asmaricus and Archias sp. Figures 4-7 shows relationship between sequence stratigraphy evidences with identified biozones and sequence microbiostratigraphy models in study area.

\section{Conclusions}

Based on field and laboratory studies such as microfossils, microbiostratigraphy, microfaceis, sedimentary and sequence stratigraphy evidences recognized 3 depositional models based on relative sea level change that themes presented during Paleocene-Oligomiocene in study area.

Jahrum formation consists of one depositional sequence and Asmari formation consists of two depositional sequences.

Microfossils and microbiostratigraphy studies in study area will lead to the identification of 6 biozones in studied area.

In Beyza and Estahban sections biozones 1, 2 and 3 are related to Jahrum formation and suggest Paleocene to Middle Eocene age for this formation and biozone 4 is related to Asmari formation and suggests Oligocene age for this formation.

In Sarvestan section biozones 1, 2 and 3 are related to Jahrum formation and suggest Paleocene to middle Eocene age for this formation and biozones 4 and 5 are related to Asmari formation and these biozones indicate a Oligocene-Miocene (Aquitanian) age for Asmari formation in this section.

Sequence microbiostratigraphy studies in study area indicate that biozones of Jahrum formation are formed in DS1 and biozones of Asmari formation are formed in DS2 and DS3.

Sequence microbiostratigraphy studies indicated some relationship between depositional sequences parameters and distribution of microfossils and biozones in study area as in the case of:

SB1. LST facies are often excessive in SB1 and in these facies, fauna and flora are not found, although it is possible that some reworked microfossils exist, furthermore we can't suggest biozonation. Also some parts of depositional sequence and biozons are eroded and eliminated. For example in all sections in study area upper part of HST of DS1 (Jahrum formation) and some biozones related to upper Eocene have been eliminated, for example in Estahban, Sarvestan B and Beyza sections all biozones related to Upper Paleocene to Middle Eocene and eliminated biozones of upper Eocene.

SB2. In study area SB2 existed in lower boundary of DS1 (between Sachun and Jahrum formations) and between DS2 and DS3 of Asmari formation. Some parts of biozones in study area could correlate with SB2. For example upper limit of biozones no 4 in Estahban section overlies to SB2 of DS2 in Asmari formation.

LST. This system tract is located between Jahrum and Asmari formations in all studied sections in over SB1 and beginning of DS2 (Asmari formation). Paleo ecological situation in LST is not suitable for foraminifer's growth and reproduction and this system tract doesn't have any index micro fauna and flora.

TST. In studied area this system tract includes marine deposits such as thin to medium limestone and dolomitic limestone in this system tract Paleoecological situation which is suitable for reproduction and growth large foraminifera. For example in Beyza and Estahban sections in biozone 1 (Jahrum formation) and biozone 2 (Asmari formation test of large foraminifera often formed hyaline micro crystalline calcite.

MFS. MFS and MFZ in all sections are recognized by mixed pelagic and benthonic foraminifera wackestone in Jahrum and Asmari formations. These microfacies formed in deep lagoon and open marine sub-sedimentary environments. There are commonly widespread thin bedded concentrations of fauna (condensed sections) with high abundant and diversity.

HST. In studied area more biozones have been identified in this system tract. For example in Beyza section 
biozones 2 and 3 (Jahrum formation) and biozone 4 (Asmari formation) are in HST. In Saevestan B section biozones 3 and 4 (Jahrum formation) and biozones 5 and 6 (Asmari formation) are in this system tract. In Estahban section biozones 3 and 4 (Jahrum formation) and biozones 4 and 5 (Asmari formations) have been in HST.

Tests of most identified large foraminifera in HST such as Alveolona sp, Alveolina aragonensis, Austrotrilina sp, Austrotrilina asmaricus and Archias sp. microfossils in HST are made of porcelaneous calcite.

Tests of most identified large foraminifera in TST such as Nummulites sp. Nummulites intermedius, Nummulites fichtelli and Operculina sp in TST are made of hyaline calcite.

\section{Acknowledgements}

This study supported with research project of Islamic Azad University Estahban Branch, Estahban, Iran and the Author appreciates for providing the financial support.

\section{References}

[1] Motiei, H. (1993) Stratigraphy of Zagros. Treatise on the Geology of Iran, Geological Survey of Iran, no1, 536.

[2] Wynd, J.G. (1965) Biofacies of the Iranian Oil Consortium Agreement area. Iranian Oil Operating Companies, Geological and Exploration division. Resport No. 1082.

[3] Adams, C.G. and Bourgeois, E.D. (1967) Asmari Biostratigraphy: Geological and Exploration Division: Iranian Oil Offshore Company, 1074, (unpublished).

[4] Laursen, G.V., Monibi, S., Allan, T.L., Pickard, N.A.H., Hosseiney, A., Vincent, B., Hamon, Y., van Buchem, F.S.P., Moallemi, A. and Druillion, G. (2009) The Asmari Formation Revisited Changed Stratigraphic Allocation and New Biozonation: First International Petroleum Conference \& Exhibition Shiraz, Iran, B29.

[5] Alavi, M. (1994) Tectonic of Zagros Orogenic Belt of Iran. New Data and Interpretations Tectonophysics, 229, 211238. http://dx.doi.org/10.1016/0040-1951(94)90030-2

[6] Dunham, R.J. (1962) Classification of Carbonate Rocks According to Their Depositional Texture. AAPG M, 1, 108121.

[7] Flugel, E. (2004) Microfacies of Carbonate Rocks, Analysis, Interpretation and Application. Springer, Berlin, 976.

[8] Vail, P.R.F., Audemard, S.A.P.R., Bowman, D., Eisner, N. and Perezcruz, C. (1988) The Stratigraphic Signatures of Tectonics, Eustasy and Sedimentology—An Overview. In: Einsele, G., Ricken, W. and Seilasher, A., Eds., Cycles and Events in Stratigraphy, Berlin, Springer-Verlag, 617-659.

[9] Loeblich. A.R. and Tappan, H. (1988). Foraminiferal Genera and Their Classification. Van Nostrand Reinhold Company. New York. http://dx.doi.org/10.1007/978-1-4899-5760-3

[10] Wagoner, J.C.H.W., Posamentier, R.M., Mitchem, P.R., Vail, J.F.S., Lutit, T.S. and Hardenbol, J. (1988) An Overview of the Fundamentals of Sequence Stratigraphy and Key Definitions. In: Wilgus, C.K., Hasting, B., St. C. Kendall, C.G., Posmentier, H.W., SS, C.A.R. and Van Wagoner, J.C., Eds., Sea Level Changes: An Integrated Approach, SEPM Special Publication, 42.

[11] Nadjaf, M., Mahboubi, A., Moussavi-Harami, R. and Mirzaee, M.R. (2004) Depositional History and Sequence Stratigraphy of Outcropping Tertiary Carbonates in the Jahrum and Asmari Formations, Shiraz Area (SW Iran). Journal of Petroleum Geology, 27, 179-190. http://dx.doi.org/10.1111/j.1747-5457.2004.tb00052.x

[12] Emery, D. and Myers, K. (2006) Sequence Stratigraphy. Blackwell Science, Oxford, 297.

[13] Schlager, W. (2005) Carbonate Sedimentology and Sequence Stratigraphy. SEPM, 200. http://dx.doi.org/10.2110/csp.05.08

[14] Zhang, X.Q., Lin, J.N. and Li, G. (2006) Non-Marine Cretaceous-Paleogene Boundary Section at Datang of Nanxiong, Northern Guangdong. Journal of Stratigraphy, 30, 327-340 (in Chinese).

[15] Marcelle, K. and Boudagher, F. (2008) Evolution and Geological Significance of Larger Benthic Foraminifera. Elsevier, B.V. 540.

[16] Adabi. M.H., et al. (2008) Applications of Nummulitids and Other Larger Benthic Foraminifera in Depositional Environment and Sequence Stratigraphy: An Example from the Eocene Deposits in Zagros Basin, SW Iran. Springer-Verlag, Facies. http://dx.doi.org/10.1007/s10347-008-0151-7

[17] Van Buchem, F.S.P., Allan, T.L., Laursen, G.V., Lotfpour, M., Moallemi, A.S., Mobini, M., Pickard, H., Tahmasbi, N.A.H., Vedrenne, A.R.N.A.H.V. and Vincent, B. (2010) Regional Stratigraphic Architecture and Reservoir Types of the Oligo-Miocene Deposits in the Dezful Embayment (Asmari and Pabdeh Formations) SW Iran. Geological Society, London, Special Publications, 329, 219-263. 
[18] Amirshahkarami, M., Vaziri-Moghaddam and Taheri, A. (2007) Sedimentary Facies and Sequence Stratigraphy of Asmari Formation at Chaman-Bolbol Zagros Basin Iran. Journal of Asian Earth Sciences, 29, 947-959.

[19] Amirshahkarami, et al. (2010) Biostratigraphy and Paleoenvironment of the Larger Benthic Foraminifera in Wells Sections of the Asmari Formation from the Rag-e-Safid Oil Field, Zagros Basin, Southwest Iran. Stratigraphy and Sedimentology Researches, 40, 63-84.

[20] Mirzaee Mahmoodabadi, R. (2013) Depositional Environments and Sequence Stratigraphy of Paleocene-Eocene Sediments in Shiraz Area, Fars, Zagros, Iran 30 IAS (International Association of Sedimentology), Oral, Manchester.

[21] Mirzaee Mahmoodabadi, R. (2013) Paleoecology and Quantitative Study of Bentonic and Pelanktonic Foraminifera of Pabdeh Formation Based on Sequence Stratigraphy Evidences in Shiraz, Fars, Zagros, Iran, 30 IAS (International Association of Sedimentology), Poster, Manchester.

[22] Mirzaee Mahmoodabadi, R. (2014) Sedimentary Environments and Correlative Sequence Stratigraphy of Upper Cretaceous-Paleogene Succession in Shiraz Area, Fars, SW IRAN. Open Journal of Geology, 4, 1-17. http://dx.doi.org/10.4236/ojg.2014.41001 